\title{
Capital Structure and The Profitability of Listed Retail Firms
}

\author{
Jason Stephen Kasozi \\ University of South Africa, Pretoria, South Africa \\ kasozjs@unisa.ac.za
}

\begin{abstract}
The South African retail sector continues to experience a decline in sales and returns amidst growing external competition and a drop in consumer confidence stemming from the recent credit downgrades in the country. Yet, firms in this sector appear to maintain high debt to equity levels. This study investigated whether the capital structure practices of these firms influence their profitability. A Panel data methodology, using three regression estimators, is applied to a balanced sample of 16 retail firms listed on the Johannesburg Securities Exchange (JSE) during the period 2008-2016. The analysis estimates functions relating capital structure composition with the return on assets (ROA). Results reveal a statistically significant but negative relationship between all measures of debt (short-term, long-term, total debt) with profitability, suggesting a possible inclination towards the pecking order theory of financing behaviour, for listed retail firms. Additionally, retail firms are highly leveraged yet over $75 \%$ of this debt is short-term in nature. Policy interventions need to investigate the current restrictions on long-term debt financing which offers longerterm and affordable financing, to boost returns. While this study's methodology differs slightly from earlier studies, it incorporates vital aspects from these studies, and simultaneously specifies a possible model fit. This helps to capture unique but salient characteristics like the transitional effects of debt financing on firm profitability. It therefore delivers some unique findings on the financing behaviour of retail firms that both in form policy change, while stimulating further research on the phenomenon.
\end{abstract}

Keywords: Capital Structure, Profitability, Return on assets, Leverage, Debt, Retail firms.

\section{Introduction}

Evaluating the financial performance of retail firms in South Africa occupies a prominent space in the corporate finance literature particularly because current socio-economic challenges in this sector indicate high consumer debt-to-income ratios and rising utility costs that negatively impact the disposable income of households and eventually erode the forecasted revenues of the sector (Euro monitor International, 2017).This First Moving Consumer Goods (FMCG) sector, by its very nature, implies strong links between the acquisition and utilisation of operational debt, with financial performance, which, for this study, raises the empirical question; what form of debt financing is sufficient to sustain profitability and growth in this sector?

The debate on firm capital structure and its relevance to financial performance remains unresolved stemming from the 1958 seminal works of Modigliani and Miller (MM) who under perfect market conditions found no relevance of debt to firm performance. Since then, numerous studies have documented a more realistic approach to the use of debt, citing cases where firms under capital market imperfections will trade-off the costs and benefits of debt in order to maintain target debt-equity ratios. Conversely, they will initially finance their investments through internally generated funds and only issue debt when the latter are insufficient, thereby a deviating from the target debt-to-equity phenomenon (see; Myers, 1984; Rajan \& Zingales, 1995; Fama \& French, 2002 and Flannery \& Rangan, 2006). Similarly, other capital structure theories arising out of empirical contention reject the possibility of a timely convergence towards a target debt-to-equity ratio and suggest, among others, management's ability to trade overpriced shares in a market-timing fashion, when information asymmetries exist (Baker \& Wugler, 2002; Flannery \& Rangan, 2006). Such cases indicate that firms rarely converge to absolute target debt ratios (or that the process of doing so takes time!), implying a possible dynamic nature of most firms' capital structures, with potential advantages and disadvantages for creating value.

Debt financing, according to theorists, has its known pros and cons. According to Graham, (2012) and Brigham and Daves, (2015), it increases firm value since payments on debt are tax deductible and create savings for borrowers that eventually reduce the cost of debt. However, accumulated debt increases the risks that shareholders have to bear and potentially causes financial distress or a possibility for bankruptcy. The retail sector in South Africa is faced with a myriad of potential challenges ranging from increased growth in 
external competition and the use of excess debt, to a decline in consumer confidence amidst the recent credit downgrades in the country (Fin24: 2017). According to a report by Fin24 (2017) and StatsSA (2017), while food retailers continued to experience stable sales despite the bleak economic conditions, other retail groups experienced a decline amidst rising input costs, putting pressure on their anticipated profit margins. Additionally, StatsSA (2016) indicates that this sector is highly leveraged with debt-to-equity ratios in ranges of 2.3:1. Simultaneously, a significant portion of the sales in this sector are managed by way of credit which exerts pressure on operating cash flows and exacerbates the financing problem.

This raises the need to empirically investigate what particular combination and/or amount of debt securities enhance the overall value of firms in this sector? To the best of the researcher's knowledge, no empirical studies could be found investigating the effect of capital structure on financial performance for listed retail firms in South Africa. While studies on capital structure exist in general, several have concentrated on other industries and sectors within the economy thereby creating a gap in the empirical literature on capital structure. This study seeks to empirically investigate whether the capital structure of listed retail firms on the Johannesburg Securities Exchange (JSE) influences their financial performance. To achieve this objective, the following secondary objectives were identified:

- To investigate the relationship between short-term debt and the profitability of retail firms listed on the JSE.

- To investigate the relationship between long-term debt and the profitability of retail firms listed on the JSE.

- To investigate the relationship between total debt and the profitability of retail firms listed on the JSE

- Comment on the overall impact of capital structure on the profitability for retail firms listed on the JSE.

The rest of this paper is organized as follows: Section 2 highlights the relevant empirical findings on the capital structure and financial performance relationship. Section 3 outlines on the research design and methodology. Section 4 presents the data analysis process and results, while the last section concludes by discussing the results and their policy implications.

\section{Literature Review}

The debate on capital structure and profitability remains contentious since the seminal works of Modigliani and Miller, (1958) hereafter MM (1958), whose original theory of "capital structure irrelevance" was based on restrictive assumptions that posited an absence of taxes and/or transaction costs, perfect capital markets and market participants with homogenous expectations. Once relaxed under MM (1963), it became apparent that the presence of bankruptcy costs and favourable tax-shields, favour the notion of an optimal capital structure - one which maximises firm value or respectively minimises the cost of capital (Abor, 2005).

Subsequent empirical studies further disputed the revised MM (1963), assertion that firms should use as much debt as possible in their capital structure to maximise value. This culminated in the advancement of other capital structure theories that include, but are not limited to; the bankruptcy costs theory (Titman, 1984), the agency theory (Jensen and Meckling, 1976) and the pecking order theory (Myers and Majluf, 1984). In all these cases firms' capital structures seem more dynamic than static. Frank and Goyal, (2003), categorically state that different theories apply to firms under different conditions so that "there is no universal theory of capital structure and no reason to expect one" (Myers, 2002). Against such backdrop, current empirical studies focus more on accessing reliable empirical patterns of debt-equity use and aligning them to the different theories as postulated. The financing pattern of a particular firm or its mixture of debt to equity provides an indicator of the particular theory or financing behaviour adopted by the firm. This takes precedence over the controversial posits presented by capital structure theorists.

For instance, Abor (2005) investigates the effect of capital structure on profitability (measured using the return on equity, ROE) on a panel sample of listed firms on the Ghanaian Stock Exchange during the period 1998 - 2002.Using an Ordinary Least Squares (OLS) regression technique, he confirms that most profitable firms use more short-term debt to finance their operations implying that short-term financing is an important component of financing for Ghanaian firms. In fact, $85 \%$ of the total debt on the Ghanaian Securities Exchange 
comprises of short-term debt. He observes that firms that finance using long-term debt become less profitable in the long run (Abor, 2005). These findings mirror studies by Frank and Goyal, (2003) and Nimalathasan and Brabete, (2010) who found positive correlations between debt and firm profitability for United States (US) firms and listed firms in Sri Lanka respectively.

Conversely, Javed and Akhtar, (2012) investigate this relationship using industrial sector firms on the Karachi Stock Exchange (KSE). Their sample is selected from 21 diversified industries with public limited companies registered on this exchange during the period 2004 - 2008. Using correlations and regression analyses, and contrary to the above findings, their study confirms a statistically significant but negative relationship between the debt-to-equity ratio and their profitability measure - the ROE. However, when the return on total assets (ROA) is used as a proxy for profitability, their findings confirm a statistically significant but positive relationship. Their initial findings align with studies by Rajan and Zingales, (1995) and in part, with those by Mirza and Javed, (2013) and Muneer (2015) indicating that excessive financing with debt sources negatively impacts profit margins due to heavy interest payments. This means that firms that have too much financing done through long-term debt, reduce their earnings by increasing their mark-up expenses (Mirza \& Javed, 2013).

Amidu, (2007) also assesses the determinants of capital structure by applying a panel regression model on banks in Ghana. His supporting theories on the capital structure - profitability relationship are adopted from Ooi, (1999) who argues that firms that employ more debt become more profitable since they merely have a high tax burden but low bankruptcy risk, and Myers, (1984) who prescribes a negative relationship on the basis that profitable firms do not need to depend on so much external financing because they usually have adequate internal reserves. His findings support the former theory only in the sense that profitable banks employ more long-term debt. However, like Abor (2005), firms in his study rely mostly on short-term debt and the latter seems to have a negative impact on profitability. Conversely, Kyereboah-Coleman, (2007) assesses this relationship using microfinance institutions in Ghana. His panel consists of all microfinance institutions listed during the period 1995 - 2004, and is analysed using both fixed and random effects regression models. He confirms exclusively that most microfinance institutions employ a lot of debt in their capital structure and that such debt is of a long-term rather than short-term nature. He observes that these highly leveraged institutions build economies of scale and are better able to deal with cases of adverse selection and moral hazards, thereby enhancing their ability to deal with risk.

In another study, Ahmad, Abdullah and Roslan, (2012) investigate this relationship focusing on publicly listed firms in Malaysia. Their study incorporates several extraneous variables known to conventionally influence the debt -profitability relationship like; growth, size and efficiency. In addition, they use both measures of profitability (ROE and ROA) and also incorporate lagged debt variables in order to capture transitional effects if any. Their findings indicate that all forms of debt financing (short-term, long-term and total) are significantly positive to the ROE, while only short-term debt and total debt vary positively with the ROA. Additionally, their control variables vary significantly with both measures of profitability in directions prescribed by earlier empirical findings. However, the lagged variables of debt do not have a significant impact of profitability implying that previous years' debt does not significantly influence performance. In contrary to the above studies, Ahmad et al. (2012) confirm that all forms of debt financing influence firm profitability in a positive manner (Muneer et al., 2013).

Therefore, these findings suggest a set of plausible conclusions. First, it is evident that firms, even within the same environmental context, employ debt financing differently based on their pressing economic constraints. To this end, it is impossible to classify firms with certainty, to one theory or another since their financing behaviour tends to overlap more than one theory. Secondly, and flowing from the above, it is logical to classify firms based on their debt financing patterns rather than capital structure theory per se. It is necessary to classify the financing behaviour of firms based on the debt-to-equity composition, size, tax implications, profitability, growth prospects and chances of bankruptcy, among others. Hence, in order to further the literature on capital structure, and to verify the conflicts among several empirical studies, this study adopts an approach similar to Abor, (2005), Amidu, (2007) and Ahmad et al. (2012), to investigate the effect of capital structure on profitability for listed retail firms on the Johannesburg Securities exchange (JSE). 


\section{Methodology}

The study adopted a panel data methodology similar to studies by Ismail, (2013), Ahmad et al. (2012), Amidu, (2007), Kyereboah-Coleman, (2007) and Abor, (2005) to investigate the effect of capital structure on profitability among listed retail firms on the JSE. According to Baltagi (2005), panel data methodology pools cross-sectional units of observations over several time dimensions and produces estimates that are more robust than employing cross-sectional or time-series estimation techniques alone. It also assumes that the variables are heterogeneous thereby controlling for bias and ensuring less collinearity but greater degrees of freedom.

All the above studies use a conventional weighted least squares methodology due to the nature of the panel data they apply since such a methodology controls for cases of possible heteroscedasticity and autocorrelation amongst the variables. The study adapts this approach in two aspects; firstly, it specifically isolates the various components of debt yet includes them into one specified model in order to assess the explanatory power of the latter, secondly, it lags certain components of debt financing in order to investigate for any possible transition effects in the debt - profitability relationship. It therefore differs from studies by Afrasiabi and Ahmadinia, (2011); Mazur, (2007) and Ortqvist et al. (2006) that apply a variant of structural equation modelling techniques in order to investigate capital structure theories and the effect of other macro and/or micro economic variables on profitability.

Sample and Data: The study employed audited financial statement data from Orbis - a flagship of the Bureau Van Dijk (BvD) database which contains financial and economic information on private and listed companies. The sample consisted of all retail firms listed on the JSE during the period $2008-2016$. According to the North American Industry Classification System (NAICS 2017), the original sample consisted of an unbalanced sample of 19 firms grouped into two sub-sectors (code44 -motor parts, electronics, furniture, building materials, food and beverages, healthcare and clothing stores and code 45 - general merchandise, sporting and miscellaneous retailers). In order to create a balanced data panel, three firms with a non-random nature of missing data, were removed from the sample to create a balanced panel of 16 firms, with 144 firm-year observations. The Bureau Van Dijk database standardises financial statement data based on a particular reporting period (usually a year) and according to major business characteristics defining a particular industry and/or sector. Using a particular base year, this data is then converted into several global currencies for the purpose of analysis. For this study, pre-calculated financial statement ratios were extracted in thousands('000's) of rand values and used for the analysis.

Variables: For consistency, both measures of profitability (ROA and ROE) where considered in the preliminary analysis (see; Mirza \& Javed, 2013 and Ahmad et al., 2012; Muneer et al., 2017). Unfortunately, the analysis with the ROE was weak across most estimations and dropped from the analysis. The return on assets (ROA) was operationalized as the dependent variable and a proxy for profitability. This proxy is defined as the ratio of earnings after taxes (EAT) to total assets and relates a company's profitability to its asset base (Ahmad et al., 2012).

Other proxies operationalized as independent variables and measures of capital structure included; a measure of short-term debt (SDA) calculated as a ratio of the firm's short-term debt to total assets, a measure of long-term debt (LDA) calculated as the ratio of the firm's long-term debt to total assets, the total-debt-tototal assets ratio representing total debt (TDA), and a differenced total debt-to-total asset measure (DTDA) to capture transitional effects of debt over time. Then, following Abor, (2005) and Amidu, (2007), two control variables that affect the validity of the study if excluded, were added as explanatory variables, in order to increase model robustness. These included; size of the firm (LSALES) calculated as the natural logarithm of sales per year and growth (SGROW) calculated as (Sales1 - Saleso)/Saleso.

Since empirical findings on the debt - profitability relationship are mixed and most analyse debt as a collective, this study followed certain empirical postulates to hypothesise the relationships. The study followed Abor (2005) and Amidu, (2007) to hypothesise a positive relationship between short-term debt (SDA) and profitability (ROA) since such debt is less expensive, has lower interest commitments and therefore enhances profits (Abor, 2005). Conversely, it hypothesises a negative relationship between long- 
term debt (LDA) and profitability (ROA) since according to Fama and French, (2002), Graham, (2005) and Abor, (2005) such debt commits a firm to high proportions of interest payments over longer periods and potentially affects the returns. The study also assumes that total debt (TDA) will vary positively with profitability based on the conventional knowledge that "the higher the debt, the higher the profitability" (Abor, 2005). Finally, the general consensus about the size of the firm (LSALES) and growth (SGROW) is that both affect debt positively as a "rule of thumb" (Abor, 2005; Amidu, 2007 and Mirza \& Javed, 2013).

\section{Data Analysis and Results Discussion}

The study employs a basic panel data regression equation adopted from Kyereboah-Coleman, (2007) but similar to Amidu, (2007) and Abor, (2005). The model is specified as follows:

Profitability $_{i t}=\beta+\beta$ Debt $_{i t}+\beta$ Controlit $_{i}$

Where Profitabilityit represents the performance of firm i at time t, Debt $t_{i t}$ represents the specific debt employed by firm i at time $t$ and Controlit represents the control variables of firm i at time $t$.

Following from equation (1), the following regression equations were estimated using Ordinary Least squares (OLS), Fixed Effects (FEM) and Random Effects (REM) estimation techniques:

$R O A_{i t}=\beta_{0}+\beta S D A_{i t}+\beta L D A_{i t}+\beta T D A_{i t}+\beta L S A L E S_{i t}+\beta S G R O W_{i t}+e_{i t}$

$R O A_{i t}=\beta 0+\beta S D A_{i t}+\beta L D A_{i t}+\beta D T D A_{i t}+\beta L S A L E S_{i t}+\beta S G R O W_{i t}+e_{i t}$

Where, the ROA denotes a measure of the firms' return on assets, $S D A$ measures the amount of short-term debt, $L D A$ measures the amount of long-term debt, TDA measures the amount of total debt, DTDA measures the differenced total debt, LSALES measures the size of the firm and SGROW measures growth level in sales terms. The subscript $i$ denotes the cross-sectional dimension of firms ranging from $1-16$ while $t$ denotes the time-series dimension of years ranging from 2008 to 2016. $\beta$ estimates the coefficients of the independent variables and $e$ the error term. The study uses a balanced panel of data and Eviews 9 to estimate these models.

Table 1: Descriptive results of all variables over the 9-year period

\begin{tabular}{lllllll}
\hline & ROA & SDA & LDA & LSALES & SGROW & TDA \\
\hline Mean & 14.61 & 0.409 & 0.082 & 12.87 & 79.34 & 0.511 \\
Median & 14.85 & 0.395 & 0.047 & 13.27 & 0.004 & 0.527 \\
Maximum & 48.16 & 0.853 & 0.446 & 16.19 & 11256 & 0.880 \\
Minimum & -59.94 & 0.043 & 0.0008 & 8.168 & -0.995 & 0.092 \\
Std. Dev. & 15.08 & 0.210 & 0.092 & 2.122 & 937.9 & 0.197 \\
Skewness & -0.701 & 0.296 & 2.146 & -0.461 & 11.87 & -0.174 \\
Kurtosis & 6.950 & 2.063 & 7.786 & 2.252 & 141.9 & 2.211 \\
Jarque-Bera & 105.4 & 7.374 & 248.0 & 8.465 & 119262. & 4.467 \\
Probability & 0.000 & 0.025 & 0.000 & 0.014 & 0.000 & 0.107 \\
Sum & 2105 & 59.01 & 11.88 & 1853. & 11426 & 73.64 \\
Sum Sq. Dev. & 32543 & 6.312 & 1.231 & 644.2 & $1.26 \mathrm{E}+08$ & 5.597 \\
Observations & 144 & 144 & 144 & 144 & 144 & 144 \\
\hline Where:
\end{tabular}

Where: ROA = return of assets, $S D A=$ short-term debt, LDA denotes the long-term debt, TDA = total debt, LSALES represents size measured using the natural logarithm of sales and SGROW = growth in sales. ALL variables estimated for an annual cycle. 
Table 2: Pearson's Correlation Analysis

\begin{tabular}{|c|c|c|c|c|c|c|}
\hline $\begin{array}{l}\text { Correlation } \\
\text { Probability }(p)\end{array}$ & ROA & SDA & LDA & DTDA & LSALES & SGROW \\
\hline ROA & 1.000 & & & & & \\
\hline SDA & $-0.3016^{* * *}$ & 1.000 & & & & \\
\hline$p$-value & 0.0005 & & & & & \\
\hline LDA & $-0.2807^{* * *}$ & $\overline{-0.4103^{* * *}}$ & 1.000 & & & \\
\hline$p$-value & 0.0013 & 0.0000 & & & & \\
\hline DTDA & $-0.1748^{* *}$ & 0.0879 & $\overline{0.0057}$ & 1.000 & & \\
\hline$p$-value & 0.0485 & 0.3237 & 0.9491 & & & \\
\hline LSALES & $0.5013^{* * *}$ & 0.1297 & -0.1061 & $\overline{0.0340}$ & 1.000 & \\
\hline$p$-value & 0.000 & 0.1443 & 0.2333 & 0.7025 & & \\
\hline SGROW & -0.0012 & 0.0495 & -0.0551 & -0.0042 & $\overline{0.1309}$ & 1.000 \\
\hline$p$-value & 0.9895 & 0.5786 & 0.5367 & 0.9623 & 0.1406 & \\
\hline
\end{tabular}

Where: $\left({ }^{*}\right)\left({ }^{* *}\right)$ and $\left({ }^{* * *}\right)$ represent statistical significance at the $10 \%, 5 \%$ and $1 \%$ levels respectively. Included observations: 128 after adjustments Balanced sample (listwise missing value detection)

Where: $R O A=$ return on assets, $S D A=$ short-term debt, $L D A$ denotes the long-term debt, DTDA is the value of the differenced (lagged) total debt, LSALES = size of the firm and SGROW = growth measured by a change in sales. All variables estimated for an annual cycle.

Descriptive statistics: Table I above presents the descriptive statistics of the estimates for normality. Of all 16 retail firms, the average ROA was $14.6 \%$ with a maximum of $48 \%$ and a minimum $-59 \%$. The standard deviation of $15.1 \%$ does not suggest a wide variation in the distribution of this measure. The variable SDA which measures the ratio of short-term debt to total assets has an average of $41 \%$ and a median of $40 \%$ implying that about $40 \%$ of all retail firms' debt is short-term in nature. The long-term debt (LDA) ratio on the contrary indicates an average debt-to-assets level of $8.25 \%$ and a median of $4.7 \%$ implying that most retail firms carry less than 5\% long-term debt in their capital structures and as noted by Abor, (2005), seem to depend mostly on short-term financing to run their operations. It is possible that the acquisition of longterm financing from financial institutions is a cumbersome process. Slightly over $52 \%$ of firm's assets are financed by debt while for some firms this value raises to $88 \%$. These results imply that retail firms are highly leveraged yet the majority of their debt is short-term in nature. A Pearson's Correlation analysis of the variables under study indicated the causality between the dependent and independent variables. This is presented in table 2 above.

Table 2 above indicates the bivariate values of correlations between the dependent and independent variables. First, it is observable that cases of multicollinearity were negligible. According to Garcia-Teruel and Martinez-Solano, (2007) cases of multicollinearity are considered severe when correlations among particular independent variables exceed the $80 \%$ level. Such a correlation existed between the variables TDA and SDA and the study adopted a lagged variable for TDA (DTDA) in order to eliminate the problem. Additionally, and according to Ahmad et al. (2012), a lagged variable helps to capture the transitional effects of one variable on another. In this case, using lagged values of total debt (TDA) improved the robustness of the model(s).

Secondly, the correlations between the dependent and independent variables confirm interesting findings. Accordingly, all debt variables (SDA, LDA and DTDA) negatively impact the performance of retail firms since all variables indicate negative but statistically significant correlation coefficients with profitability. This finding conflicts with studies by Abor, (2005), Amidu, (2007) and Kyereboah-Coleman, (2007) and suggests unique implications for the retail industry in South Africa. It is possible that while most retail firms finance with short-term debt as opposed to long-term debt, the excess levels of debt in the sector are negatively impacting the performance of firms. However, size positively and significantly affects profitability, while growth in the industry indicates an inverse relationship although this finding is insignificant. Consequently, further analysis to these findings was warranted since according to Padachi's (2016), Pearson's correlation coefficients do not, in isolation, provide a reliable indicator of association because they do not account for each variable's correlation with other independent variables. Therefore, this study further estimated its theoretical multivariate models' using the pooled ordinary least squares (OLS) estimation, the fixed effects 
estimation (FEM) and the random effects estimation (REM). While the analysis justifies the use of a suitable estimator, it is necessary to compare the findings across other alternatives.

Table 3: Multivariate Regression estimates for equation 2 using Pooled OLS, REM and FEM

\begin{tabular}{|c|c|c|c|}
\hline & Pooled OLS & Random Effects (REM) & Fixed Effects (FEM) \\
\hline \multirow{2}{*}{ constant } & $-12.19^{* *}$ & $-8.46^{* *}$ & 11.76 \\
\hline & $(0.04)$ & $(0.045)$ & $(0.56)$ \\
\hline \multirow{2}{*}{ SDA } & 3.516 & -0.609 & 2.495 \\
\hline & $(0.813)$ & $(0.964)$ & $(0.869)$ \\
\hline \multirow{2}{*}{ LDA } & $-46.31^{* * *}$ & $-43.425^{* * *}$ & $-39.845^{* * *}$ \\
\hline & $(0.002)$ & $(0.002)$ & $(0.005)$ \\
\hline \multirow{2}{*}{ TDA } & $-44.66^{* * *}$ & $-33.536^{* * *}$ & $-30.296^{* *}$ \\
\hline & $(0.002)$ & $(0.008)$ & $(0.0162)$ \\
\hline \multirow{2}{*}{ LSALES } & $3.973^{* * *}$ & $3.428^{* * *}$ & 1.604 \\
\hline & $(0.000)$ & $(0.000)$ & $(0.303)$ \\
\hline \multirow{2}{*}{ SGROW } & -0.001 & -0.001 & -0.001 \\
\hline & $(0.153)$ & $(0.160)$ & $(0.474)$ \\
\hline \multirow{2}{*}{ F-statistic } & $41.21^{* * *}$ & $14.92^{* * *}$ & $20.559 * * *$ \\
\hline & $(0.000)$ & $(0.000)$ & $(0.000)$ \\
\hline Adjusted $\mathrm{R}^{2}$ & $58.43 \%$ & $32.74 \%$ & $73.23 \%$ \\
\hline Observations & 144 & 144 & 144 \\
\hline
\end{tabular}

Where: $\left({ }^{*}\right)\left({ }^{* *}\right)$ and $\left({ }^{* *}\right)$ represent statistical significance at the $10 \%, 5 \%$ and $1 \%$ levels respectively. $p$-values in parenthesis.

Where: $R O A=$ return of assets, $S D A=$ short-term debt, $L D A$ denotes the long-term debt, TDA = total debt, LSALES = size of the firm and SGROW = growth of the firm measured by the change in sales. ALL variables estimated for an annual cycle.

Data analysis: Estimating models using panel data requires a determination of whether there exists a correlation between the unobservable heterogeneity of each firm and the independent variables within a model (fixed effects). This helps to ascertain whether a within-group estimator or a random effects estimator is more appropriate for the analysis (Garcia-Teruel\& Martinez-Solano, 2007). In order to determine the appropriate estimator for the short panel data used in this study, a Hausman (1978) test (test for the null hypothesis of no correlation) was run on a random effects regression estimation. The obtained statistically insignificant $p$-value of 0.2613 meant that the null hypothesis could not be rejected hence; a random effect model (REM) was adopted as the best estimator for the panel data. According to Raheman and Nasr (2007), a random effects model counters the problem of heteroscedasticity by calculating a common weighted intercept for all variables. This generalised least squares procedure normalises the data by making the weighted residuals more comparable to the un-weighted residuals thereby providing a more consistent estimation. Nonetheless, for consistency, this study reports the findings using all the 3 estimation techniques. Table III below provides the regression estimations for equation 2 below.

$R O A_{i t}=\beta_{0}+\beta S D A_{i t}+\beta L D A_{i t}+\beta T D A_{i t}+\beta L S A L E S_{i t}+\beta S G R O W_{i t}+e_{i t}$

The study estimated two similar models separated by the presence of a single variable. Observably, the total debt-to-total assets variable (TDA) was found to be highly correlated to the short-term debt (SDA) variable. This necessitated the estimation of another model using a lagged TDA variable(DTDA). It is notable that this change significantly increases the robustness of the findings. Table 3above provides the original output of equation 2 using; pooled ordinary least squares (OLS), random effects (REM) and fixed effects (FEM) estimation techniques. First, all estimation techniques produced similar findings on the relationships between LDA and TDA with profitability. Secondly, the model constants, F-statistics and R-square values 
indicated robustness on the theoretical model fits albeit the fixed effects model produced the highest estimation (adjusted $\mathrm{R}^{2}$ value of $76.56 \%$ ). Table 3 indicates that both LDA and TDA are statistically significant to profitability but vary negatively with the latter, at the $1 \%$ level. These findings mirror those by Amidu, (2007) and Abor, (2005) with regards to the LDA - profitability relationship, but differ when the total debt profitability relationship is considered. Evidently, long-term debt is more expensive and employing large amounts of it affects profitability among retail firms. Similarly, output of the estimations of SDA and SGROW with profitability, were weak to support reasonable inference. However, larger retail firms carry the most debt as indicated by the positive and statistically significant relationship between LSALES and profitability, indicated at the $1 \%$ level of significance. The above estimation procedure was repeated using a lagged total debt to total assets variable as indicated in equation 3 and table 4 below. Notably, the inclusion of a lagged variable (see equation 3 ) increases the explanatory power of the variables in the model.

$R_{O A}=\beta_{0}+\beta S D A_{i t}+\beta L D A_{i t}+\beta D T D A_{i t}+\beta L S A L E S_{i t}+\beta S G R O W_{i t}+e_{i t}$

Table 4: Multivariate Regression estimates for equation 3 using Pooled OLS, REM and FEM

\begin{tabular}{|c|c|c|c|}
\hline & Pooled OLS & Random Effects (REM) & Fixed Effects (FEM) \\
\hline \multirow{2}{*}{ constant } & $-12.53^{* *}$ & -14.32 & -8.91 \\
\hline & $(0.03)$ & $(0.213)$ & $(0.68)$ \\
\hline \multirow{2}{*}{ SDA } & $-39.258^{* * *}$ & $-28.139 * * *$ & $-19.103^{* *}$ \\
\hline & $(0.000)$ & $(0.000)$ & $(0.048)$ \\
\hline \multirow{2}{*}{ LDA } & $-74.54^{* * *}$ & $-59.952^{* * *}$ & $-55.055^{* * *}$ \\
\hline & $(0.000)$ & $(0.000)$ & $(0.000)$ \\
\hline \multirow{2}{*}{ DTDA } & $-25.01^{* *}$ & $-29.630^{* * *}$ & $-32.152^{* * *}$ \\
\hline & $(0.012)$ & $(0.000)$ & $(0.000)$ \\
\hline \multirow{2}{*}{ LSALES } & $3.812^{* * *}$ & $3.499^{* * *}$ & 2.760 \\
\hline & $(0.000)$ & $(0.000)$ & $(0.102)$ \\
\hline \multirow{2}{*}{ SGROW } & -0.001 & -0.001 & -0.001 \\
\hline & $(0.234)$ & $(0.501)$ & $(0.580)$ \\
\hline \multirow{2}{*}{ F-statistic } & $34.366^{* * *}$ & $14.92^{* * *}$ & $21.738^{* * *}$ \\
\hline & $(0.000)$ & $(0.000)$ & $(0.000)$ \\
\hline Adjusted $\mathrm{R}^{2}$ & $56.77 \%$ & $35.41 \%$ & $76.56 \%$ \\
\hline Observations & 144 & 144 & 144 \\
\hline
\end{tabular}

Where: $\left({ }^{*}\right)\left({ }^{* *}\right)$ and $\left({ }^{* *}\right)$ represent statistical significance at the $10 \%, 5 \%$ and $1 \%$ levels respectively. $p$-values in parenthesis.

Where: $R O A=$ return of assets, $S D A=$ short-term debt, LDA denotes the long-term debt, TDA = total debt, LSALES = size of the firm and SGROW = growth of the firm measured by the change in sales. ALL variables estimated for an annual cycle.

Table 4 includes a lagged variable for total-debt (DTDA) to capture the transitional effects of leverage on firm performance. This, at the one hand strengthens the explanatory power of the model, while at the other, captures new insights about the effects of a firm's previous year's debt on its profitability (Ahmad et al., 2012). Interestingly, the replacement of total debt with its lagged variable increases the explanatory power of the estimation between short-term debt and profitability. Short-term debt (SDA) affects profitability negatively at statistically significant levels of $1 \%$ across all estimations. This observation conflicts with findings by Abor, (2005); Amidu, (2007) and Kyereboah-Coleman, (2007) but aligns with findings by Ahmad et al. (2012). According to Abor, (2005), short-term debt is less expensive and increasing it creates comparatively lower interest commitments which boost firm profits. However, the negative relationship observed above and the finding that retail firms in South Africa carry almost $80 \%$ of short-term debt in their capital structure, suggests that regular short-term debt commitments negatively impact their profits in the long run. Moreover, short-term rather than long-term debt seems to be the ideal financing alternative for 
these firms given the first-moving-consumer-goods (FMCG) nature of this sector. It is interesting to note that firms in both Ghana and South Africa, rely heavily on short-term than long-term financing.

Additionally, long-term debt (LDA) negatively affects profitability at statistically significant levels of $1 \%$ across all estimations. This implies that an increase in long-term debt is associated with a decrease in profitability. This finding conflicts with studies by Kyereboah-Coleman (2007) but agrees with Abor, (2005). Long-term debt is harder to obtain and carries higher interest commitments. This offers some explanation why retail firms in South Africa carry so little in their capital structure (less than 5\%). Moreover, it is plausible that these firms match financing requirements with their operating cycles and this favours shortterm rather than long-term financing. Empirical findings estimate the debt - profitability relationship by combining the various components of debt (total debt). Of these, the common finding is that total debt should vary negatively with profitability because managers of profitable firms tend to avoid the disciplinary role of debt financing (Rajan \& Zingales, 1995). Others believe, that total debt should vary positively with profitability based on the trade-off theory premise that more profitable firms carry more debt since they have the ability to access and take on such debt, (Myers, 2002). As in table 3 above, the lagged values of total debt varied inversely with profitability and at statistically significant levels of $5 \%, 1 \%$ and $1 \%$ across the three estimations respectively (see table 4). This finding contrasts with empirical evidence from Nimalathesan and Brabete, (2010) and Abor, (2005) but aligns with findings from Amidu, (2007). It is possible that this results from the negative trend in short-term debt which constitutes about $80 \%$ of the debt in the capital structures of retail firms.

Finally, table 4 indicates that size varies positively with profitability at the $1 \%$ level, for all estimations. This finding is consistent with most empirical studies that include; Frank and Goyal, (2003); Abor, (2005) and Mirza and Javed, (2013). Yet, it receives only partial support from Amidu, (2007) who finds a positive relationship only when short-term debt is considered. Similarly, findings on the growth variable (SGROW) do not offer meaningful results due to statistical insignificance. However, the sign of causality points towards a negative direction suggesting that retail profitability does not necessary imply growth. This study incorporates several variables into theoretical models 2 and 3 in order to specify a model fit for the "effect of capital structure on profitability among retail firms". While certain important variables may have been excluded from the estimation, the robustness of the models as estimated by their respective adjusted $\mathrm{R}^{2}$ values of $56.77 \%, 35.41 \%$ and $76.56 \%$, across all estimations, provides some meaningful inference to suggest that the profitability of retail firms in South Africa is not a function of how much debt firms accrue. Alternatively, the current debt levels in this sector negatively influence the profitability of firms. This suggests alignment towards the pecking order theory of financing behaviour as opposed to the trade-off theory of financing behaviour. Also, lagged debt values seem to provide a better inference about the capital structure profitability relationship than debt for a particular period

\section{Conclusion and Policy Implications}

According to Euromonitor International, (2017), the South African retail sector is experiencing a decline in sales and returns due to the increasing international competition and a drop in the consumer/investor confidence, amidst the recent credit downgrades in the country. Therefore, the present study attempted to empirically investigate whether the capital structure practices of this sector have an impact on its profitability. Two separate models on the capital structure - profitability relationship were specified and estimated using three comparative regression procedures, whose output indicated the following:

There is a negative relationship between the capital structure of retail firms and their profitability since all measures of debt in the firms' capital structures were found to be statistically significant but negatively correlated with profitability. This seems to suggest that the sector aligns more towards a pecking order financing behaviour as opposed to a trade-off financing approach because it can be implied that the sector relies more on internally generated funds in order to generate profits. Alternatively, the retail sector is highly leveraged with more than $52 \%$ of its assets financed by debt and the resulting debt obligations negatively impact its profits.

Over $75 \%$ of the debt in the capital structure of retail firms is short-term. This unique observation implies that firms in the sector have limited access to long-term financing and therefore have to pay regular interest 
payments on their short-term debt, which negatively impacts their returns in the long run. Finally, the use of lagged debt in estimations seems to increase the robustness of the findings. While this study only employed one lagged debt variable, it is possible that future studies could confirm robust findings if they considered the applicable transitional effects of other variables in their models. Similarly, due to the sample size and the limited firm-year observations, this study analysed retail firms as a collective. It is possible that an industryspecific approach could produce somewhat conflicting results due to the distinguishing characteristics of each industry in the sector. This aspect could not be investigated due to the limited sample size per industry. Therefore, policy improvements and further research should attempt to investigate these aspects and explore why these firms use too much short-term debt at the expense of long-term debt, since the latter spreads over time and reduces the financing risks of firms over a longer horizon.

\section{References}

Abor, J. (2005). The effect of capital structure on profitability: an empirical analysis of listed firms in Ghana. Journal of Risk Finance,6(5), 438 - 445. https://doi.org/10.1108/15265940510633505.

Afrasiabi, J. \& Ahmadinia, H. (2011). How financing effect on capital structure: Evidence from the Tehran Stock Exchange. International Journal of Academic Research, 3(1), 253 - 261.

Ahmad, Z., Abdulla, N. M. \& Roslan, S. (2012). Capital structure effect on firms' performance: Focussing on consumers and industrial sectors in Malaysia. International Review of Business Research Papers, 8(5) $137-155$.

Amidu, M. (2007). Determinants of capital structure of banks in Ghana: an empirical approach. Baltic Journal of Management, 2(1), 67 - 79. https://doi.org/10.1108/17465260710720255.

Baltagi, B. H. (2005). Econometric Analysis of Panel Data. $3^{\text {rd }}$ Edition. Chi Chester: Wiley.

Baker, M. \& Wurgler, J. (2002). Market timing and capital structure. Journal of Finance, 57, 1 - 32. https://doi.org/10.1111/1540-6261.00414.

Brigham, E. F. \& Daves, P. R. (2015). Intermediate financial management. $12^{\text {th }}$ Ed. New York: Cengage Learning.

Euromonitor International. (2017). South African Statistics: Consumer lifestyles in South Africa. Available at: http://www.euromonitor.com/south-africa.

Fama, E. \& French, K. (2002). Testing the trade-off and pecking order predictions about dividends and debt. $A$ Review of Financial Studies, 15, 1 - 34. https://doi.org/10.1093/rfs/15.1.1.

Fin24. (2017). Clothing Sector seeks urgent solution to downgrades impact. Available at: http://www.fin24.com/Economy/clothing-sector-seeks-urgent-solution-to-downgrades-impact20170829

Flannery, M. J. \& Rangan, K. P. (2006). Partial adjustment toward target capital structures. Journal of Financial Economics, 79, 470 - 505. https://doi.org/10.1016/j.jfineco.2005.03.004.

Frank, M. \& Goyal, V. (2003). Testing the pecking order theory of capital structure. Journal of Financial Economics,67, 217 - 248. https://doi.org /10.1016/S0304-405X (02)00252-0.

Garcia-Teruel, P. J. \& Martinez-Solano, P. (2007). The effects of working capital management SME profitability. International Journal of Managerial Finance, $3(2), \quad$ 164-177. https://doi.org/10.1108/17439130710738718.

Graham, S. (2012). Introduction to financial management. $3^{\text {rd }}$ Ed. New York: Cengage Learning.

Hausman, J. A. (1978). Specification tests in econometrics. Econometrica, 46, 1251-1271. https://doi.org/10.2307/1913827.

Ismail, M. (2013). Determinants of financial performance: the case of general "takaful" and insurance companies in Malaysia. International Review of Business Research Papers, 9(6), 111 - 130

Javed, B. \& Akhtar, S. (2012). Interrelationships between capital structure and financial performance, firm size and growth: comparison of the industrial sector on the Karachi Stock Exchange. European Journal of Business and Management,4(15), 148 - 157.

Jensen, M. C. \& Meckling, W. H. (1976). Theory of the firm: managerial behaviour, agency costs and ownership structure. Journal of Financial Economics, 3, 305 - 360. https://doi.org/10. 1016/ 0304-405X (76) $90026-X$.

Kyereboah-Coleman, A. (2007). The impact of capital structure on the performance of microfinance institutions. Journal of Risk Finance, 8(1), 56 - 71. https://doi.org/10.1108/15265940710721082. 
Mazur, K. (2007). The determinants of capital structure choice: Evidence from Polish companies. Journal for International Advanced Economic Research, 13, 495 - 514. https://doi.org/10.1007/s11294-0079114-y

Modigliani, F. \& Miller, M. (1958). The cost of capital, corporation finance and the theory of investment. American Economic Review, 53, 261 - 297.

Modigliani, F. \& Miller, M. (1963). Corporate income taxes and the cost of capital: a correction. American Economic Review, 53, 433 - 443.

Mirza, S. A. \&Javed, A. (2013). Determinants of financial performance of a firm: Case of Pakistani Stock Market. Journal of Economics and International Finance,5(2) $43 \quad-\quad 52$. https://doi.org/10.5897/JEIF12.043.

Muneer, S. (2015). An Interaction Between Financial Practices and Firm Performance with Moderating Effect of Agency Cost in Pakistani Corporate Sector. PhD Thesis (Univesiti Teknologi Malaysia).

Muneer, S., Bajuri, N. H. \& Rehman, S. U. (2013). Moderating Effect of Agency Cost on The Relationship Between Capital Structure, Dividend Policy and Organization Performance: A Brief Literature Review. Actual Problems of Economics, 11(149), 434-442

Muneer, S., Tufail, M. S., Jamil, K. \& Zubair, A. (2017). Impact of Capital Market Expansion on Company's Capital Structure. NFC IEFR Journal of Engineering and Scientific Research, 5

Myers, S. (1984). The capital structure puzzle. Journal of Finance, 39, 469 - 506. https://doi.org/ $10.2307 / 2327916$.

Myers, S. C. \& Majluf, N. (1984). Corporate financing and investment decisions when firms have information that investors do not have. Journal of Financial Economics, 13, 187 - 221. https://doi.org/10.1016/0304-405X (84)90023-0.

Myers, S. C. (2002). Financing of corporations in Constant indices, G., M Harris, and R Stulz (eds). Handbook of the Economics of finance.

Nimalathasan, B. \& Brabete, V. (2010). Capital structure and its impact on profitability: A study of listed manufacturing companies in Sri Lanka. Young Economist Journal, 8(15), 7 - 16.

Ooi, J. (1999). The determinants of capital structure evidence on UK property companies. Journal of Property Investment and Finance,17(5), 464 - 480. https://doi.org/10.1108/14635789910294886.

Ortqvist, D., Masli, K. E., Rahman, F. \& Selvarajah, C. (2006). Determinants of capital structure in new ventures: Evidence from Swedish longitudinal data. Journal of Developmental Entrepreneurship, 11(4), 277-296. https://doi.org/10.1142/S1084946706000477.

Padachi, K. (2006). Trends in working capital management and its impact of firms' performance. An analysis of Mauritian small manufacturing firms. International Review of Business Research Papers,2(2), 45-58.

Raheman, A. \& Nasr, M. (2007). Working capital management and profitability: A case of Pakistani firms. International Review of Business Research Papers, 3(1), 279-299.

Rajan, R. \& Zingales, L. (1995). What do we know about capital structure: some evidence from international data? Journal of Finance, 1(5), 1421 - 1460. https://doi.org/10.1111/j.1540-6261.1995.tb05184.x

Statistics South Africa. (2017). Retail Trade Sales - June 2017 (P6242-1). Available at http://www.statssa.gov.za/?page_id=1859 